LETTERS TO THE EDITOR.

[The Editor does not hold himseif responsible for opinions ex. pressed by his correspondents. Neither can he underlake io retum, or to cor respond. with the writers of, rejecied inanuscripts intended for this or any other part of NATURE. No noive is taken of anonymous communications. I

The Permeability of Iron Alloys.

IN a paper in the last number of the Proceedings of the Royal Society, Prof. Barrett refers to the increased permeability conferred on iron by alloying it with aluminium, and suggests an explanation on the supposition that the aluminium would remove traces of oxygen from the iron.

Some seven years ago, in the course of a series of measurements on the magnetic properties of iron alloys, I found that aluminium, phosphorus and arsenic decreased the coercive force and hysteresis loss very considerably, whilst aluminium very largely increased the permeability - the others less so. Silicon produced little effect, but probably slightly improved the iron. On mentioning this to my colleague, Prof. Arnold, he at once pointed out that these elements are just those which increase the size of the crystals in iron. Annealing, which also improves permeability and lessens hysteresis, also increases the scale of the crystals. It is probable, therefore, that the increase of permeability due to these substances is a secondary effect due to the increased size of the iron crystals. A foreign substance might be expected to act deleteriously in two ways: (I) by occupying space better filled by iron, (2) by combining with iron and forming a less magnetic chemical compound. Phosphorus and silicon would act in both ways, aluminium in the first only, which might account for a larger difference between its indirect favourable action on the iron crystals and its direct deleterious action. It would be interesting if investigators in this direction would try to correlate their permeability measurements with the results of microscopical analysis as well as chemical.

University College, Sheffield, April Io.

\section{Reform in Mathematical Teaching.}

Some of Prof. Perry's followers seem to me to miss a point which he realises clearly - viz. that the key to the whole position is in the examination system.

(I) The strength of the present system is very great. An impending examination converts the teacher from an enemy of the idle and refractory pupil into an ally - to the comfort of all parties. The success of his pupils at examinations gives a teacher some return for his labour; otherwise he would have to comfort himself by hoping that Kipling's great lines, "Therefore praise we famous men," might some day in some degree apply to him. The realised hope would be worth ten thousand times the immediate return, but hope deferred is discounted at very heavy rates.

(2) The present system might be very much better. Examining work is often badly paid; in the main and in the Iong run, bad pay means bad work. Thring said that you might have one generation of martyrs, but the second would be cheats.

The band of fossil examiners, each with his fossil syllabus, does much more harm than Procrustes. A is clever, but he must not go beyond the syllabus; $\mathrm{B}$ is slow, but he must be bustled along and got through the course somehow.

The fate of anything new or fresh is pretty sure. There is a Cambridge yarn about some one who set his favourite question, "Define a differential coefficient," but instead of getting the expected three or four lines of cram, he got the substance of five or six pages of Harnack's new German book on the calculus. He rose to the occasion and promptly marked it 0 .

(3) But written examinations have inherent and inevitable defects, clearly indicated by Dr. Lathom "Examinations considered as a means of selection." The old style of question, which was rather reproduced than parodied by the famous "Very small elephant whose weight may be neglected, and whose coefficient of friction was $\sqrt{7}-\sqrt{3}$, , may be replaced by "The relation between the weight and length of tusk of an elephant being represented by the equation $\mathrm{W}=\mathrm{A} l^{3}+\mathrm{B} l+\mathrm{C}$," and so on ... but a system of writien examinations based on the new model would in the end be like unto the first.

The following axions are put forward in the hope that they may be condemned as truisms :-

No. I694, VOL 65]
(I) Examinations are not to be multiplied beyond necessity

(2) No examination is entitled to any confidence in which teachers or persons in close touch with the teachers have no part.

(3) Viva voce examinations are essential if weight is to be attached to the results of a single examination.

It would be most interesting if Prof. Perry, who has influence and persuasiveness, could arrange an experiment.

Get answers to a paper from a dozen candidates, good and bad mixed, have facsimile copies made, and submit them to twenty or so competent examiners. The discrepancies in the marks would, I think, be surprising.

If the examiners adopt the received plan of cutting each question into several bits and giving marks for each little bit, they will get results more concordant and more entirely out of relation to common sense or real life.

Woolwich.

THERE are two places in Prof. Perry's letter appearing in your issue of March 27 in which he mentions schoolmasters in terms of, in the one case praise, in the other blame. The first passage is where he congratulates the "reformers" "on having with them the good wishes of every thoughtful teacher of the whole country," but in the last passage he expresses the conviction that we shall " not very long remain in the foremost files of our time if we depend upon the schoolmasters." I hope that teachers are good for more than mere good wishes, and I think Prof. Perry will find that the reform he laments as scarcely within sight has not only begun, but is actually bearing fruit in the place in which, though the subject of controversy, the noise of the conflict is heard least-the schoolroom. Schoolmasters, like others, move with the times, and the "conventional schoolmaster "is a much rarer bird than the conventional examiner or the conventional inspector. I suppose syllabuses and textbooks are a necessity still, but the competent teacher of mathematics needs not to be bound by anything of the kind. Personally, I see no necessity for this ideal text-book one hears about which is to replace Euclid, and those who caricature him; we are better without a text-book at all. Let a master be engaged capable of making his own syllabus for his own pupils, and give him a free hand to introduce modern geometry, differential calculus, \&c., as he sees fit; such a man will welcome the appreciation of a competent inspector, himself a mathematician and, beyond that, a successful teacher of mathematics. As I have already hinted, reform in the schoolroom proceeds as rapidly as examiners will allow, rather more so in fact, for $I$ know that many boys learn much that no examination they have been in for, or are likely to take, tests. My own work is in such a small way that $I$ do not care much to bring it forward, but I must confess to periods of guilty satisfaction when I have robbed time from examination teaching and introduced boys, much to their interest, and I feel sure profit, to such things as coaxal circles, theory of inversion, cross ratios, and fundamentals of the integral calculus. Let the mouse help the lion!

I feel sure Prof. Perry and his fellow reformers-if they will find out what is being done on the spot by the teachers, or if the latter have as yet shrunk from any sort of attempt at reform, what their wishes and opinions are-will find convention at least as hateful to the teachers as to themselves. Of course, I am not speaking, as I am not qualified to speak, on behalf of those who form what I may term the "aristocracy" of the teaching profession; I myself and my teaching friends are mostly engaged in the small schools, large in number, situated in industrial districts, where the endowed school fights for an existence with the "technical" or even the higher-grade Board School, where boys leave between fourteen and sixteen, at the latter of which ages they are supposed to have the groundwork on which a knowledge of engineering can be built up. Yet to these Euclid must be taught. Of course, as a matter of fact, Euclid is not taught to them; they pass examinations in a subject that goes by that name, the satisfaction I personally have felt being in the reports of examiners, who, intending to reprove, have written, "the constructions and principles of proof were well known, but the wording of Euclid was not adhered to, and some points in the proofs were omitted. The riders were well done.". In these schools, "practical plane and solid geometry" is a subject taught throughout; and there is many a germ which only requires a little encouragement to bear great fruit. I think that the power behind the reformers 